\title{
FATE OF SPERMATOZOA IN CASES OF OBSTRUCTIVE AZOOSPERMIA AND AFTER LIGATION OF VAS DEFERENS IN MAN
}

\author{
A. M. PHADKE* \\ Family Welfare Bureau, Bombay 4, India
}

(Received 23rd April 1963)

\begin{abstract}
Summary. The epididymal secretions in cases of obstructive azoospermia, where the site of obstruction was distal to the body of the epididymis, were studied by means of new staining techniques for the detection of spermiophage cells. The spermiophage cells were rich in lipoid material which resembled the pigment lipofuscin. Results of such staining demonstrated that phagocytosis was the chief mechanism involved in the disposal of dead spermatozoa in the majority of such cases. Study of epididymal biopsies in these cases demonstrated that the sperm phagocytosis was chiefly intraluminal and the occurrence of extravasation of spermatozoa in the interstitial tissues of the epididymis was a rare phenomenon. Evidence is presented to show that the spermiophage cells are derived from the basal layer of cells lining the epididymal tubules and in some instances the columnar epithelial lining of the epididymal tubules manifested phagocytic properties. The possible significance of this finding, and its role in the development of auto-antibodies against spermatozoa in the host, is discussed.
\end{abstract}

\section{INTRODUCTION}

Phadke \& Phadke (1961) reported the occurrence of spermiophage cells in the epididymis in some cases of obstructive azoospermia and in the semen in selected cases of oligozoospermia. They concluded that in at least some cases of obstructive azoospermia, the dead spermatozoa were disposed of by phagocytosis. However, no attempt was then made to trace the origin of spermiophage cells. This paper describes the origin and histochemistry of spermiophage cells, and the mechanism of phagocytosis, the possible significance of which is discussed.

\section{MATERIAL AND METHOD}

The present study is based on the examination of epididymal secretions and biopsies in one hundred cases of azoospermia and five cases of severe oligozoospermia who attended the Family Welfare Bureau during the past 5 years. All

*Present address: Worcester Foundation for Experimental Biology, Shrewsbury, Massachusetts, U.S.A. 
the azoospermic patients had normal testicular biopsy findings and an obstruction in the genital passage was suspected. In seven instances, the patients gave a history of vasoligation carried out as a family limitation measure 3 to 10 years prior to the current investigation.

The epididymal fluid and the biopsies were secured when the patients were explored by Dr G. M. Phadke either for vaso-epididymal anastomosis or for the end to end anastomosis of vas deferens.

\section{EPIDIDYMAL SECRETIONS}

In ninety cases epididymal secretions were collected by incising at a site proximal to the suspected obstruction which was suggested clinically by sudden narrowing or collapse of the body or tail of the organ. In ten instances epididymal fluid was collected by aspirating the head of the epididymis. Saline solution suspensions of epididymal fluid were prepared and were studied by the following techniques:

\section{Method used}

No. cases

(1) Unstained coverslip preparations examined under light microscope

(2) Saline solution suspension studied under phasecontrast microscope

(3) Haematoxylin and eosin staining

(4) Modified scarlet red and haematoxylin staining technique (Phadke, 1963)

(5) Lillie's method for the demonstration of lipofuscin (1956)

(6) Methyl green and pyronin

The scarlet red and haematoxylin staining technique described by the author (1963) for the identification of spermiophage cells was slightly modified as follows. The smears of epididymal fluid after staining with scarlet red were stained with Harris haematoxylin for $7 \mathrm{~min}$. Differentiation was carried out by $0.5 \%$ acid alcohol and the slides were subsequently immersed in weak solution of lithium carbonate for $5 \mathrm{~min}$ to blue. If and when required, the pigment granules were restained by scarlet red for a few minutes as in the process of differentiation the scarlet red was sometimes partially decolorized.

For staining with Lillie's method fresh air-dried smears were fixed in $10 \%$ formalin for $10 \mathrm{~min}$ at the end of which they were washed with distilled water and immersed in a $0.1 \%$ solution of Nile blue in $1 \%$ sulphuric acid for 30 to 40 $\mathrm{min}$, after which the slides were placed in running water for $15 \mathrm{~min}$ and mounted in gelatin.

The methyl green and pyronin staining technique was that of Pearse (1954) for the demonstration of RNA and DNA.

\section{EPIDIDYMAL BIOPSIES}

In forty-six cases of obstructive azoospermia, epididymal biopsies were secured from a site proximal to the suspected obstruction and in five cases of oligozoospermia they were secured from the head of the epididymis. The biopsies were 


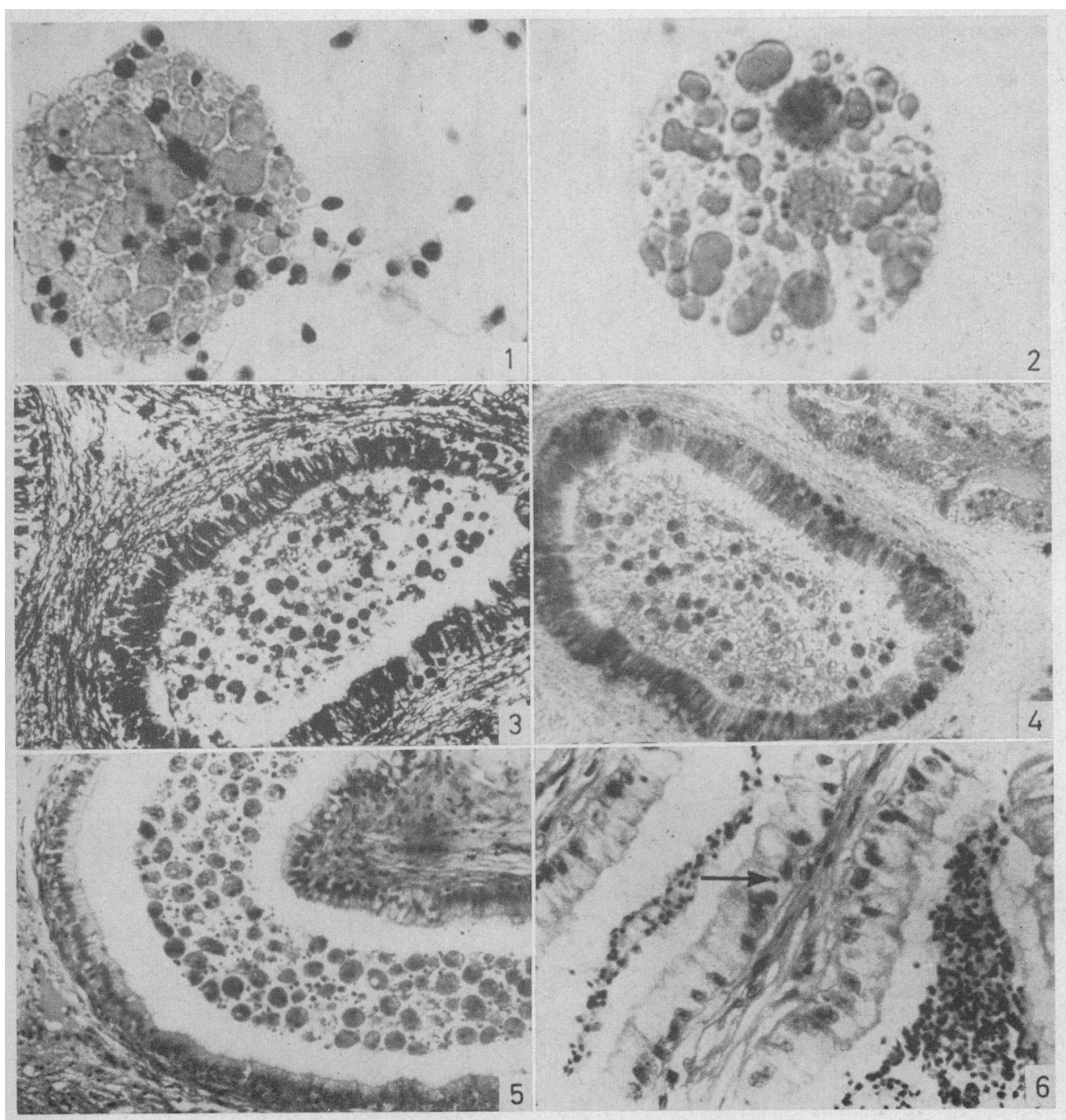

FIG. 1. A macrophage cell stained with scarlet red-haematoxylin technique; it measures $25 \times 30 \mu$. Nucleus is in the centre and appears like a bar. Ingested spermatozoa are stained bluc. $\times 500$.

FIG. 2. A macrophage cell of $10 \mu$ diameter with eccentric nucleus. The cytoplasm shows numerous lipoid granules. There is no evidence of ingested spermatozoa. $\times 500$. Fic. 3. Section of the epididymal tubule stained by Marshall's stain. Note the lining epithelial cells which are heavily stained. The intraluminal macrophages are stained black. The nuclei of the cells are not stained. In the basal layer of cells are black stained circular cells which look like in traluminal macrophages, especially at 10,11,1 and 7 o'clock position. $\times 500$.

FIG. 4. The same tubule as in Fig. 3 stained by Nilc blue. The lining epithelium is stained deep grcen and the intraluminal macrophages are stained in the same way. In the basal laycr of cells are circular cells which are stained dark grcen and which look like the intraluminal macrophages, especially at 4 and 6 o'clock position. The stroma is pale green. $\times 500$.

Fig. 5. Section of the epididymal tubule stained with haematoxylin and cosin. Numerous intraluminal macrophages with ingested sperm heads are seen. There are no similar cells in the lining epithelium. $\times 450$.

FIG. 6. Section of the epididymal tubule stained with haematoxylin and eosin. It shows one head (marked by arrow) ingested by the lining epithelium. $\times 500$.

(Facing p. 2) 
fixed in Bouin's fluid, sections were cut at $7 \mu$ and stained by the following methods: (1) haematoxylin and eosin, (2) Marshall's (1948) method of silver impregnation and (3) Lillie's methods for the demonstration of lipofuscin which consist of (a) staining with $0.05 \%$ solution of Nile blue in $1 \%$ acetic acid (1954) and (b) with $0.1 \%$ solution of Nile blue in $1 \%$ sulphuric acid (1956) for $30 \mathrm{~min}$. The slides were subsequently placed in running water for $15 \mathrm{~min}$ before mounting in gelatin.

In five instances the epididymal biopsies were fixed in formal saline solution and frozen sections were cut and stained with Lillie's methods.

In ten instances the epididymal biopsies were stained with scarlet red and haematoxylin in order to demonstrate the spermiophage cells.

\section{RESULTS}

SALINE SOLUTION SUSPENSIONS OF THE EPIDIDYMAL FLUID

Out of 100 cases of azoospermia with normal testicular biopsy findings, in fourteen instances the epididymis was only palpable and at the time of vasoepididymal anastomosis contained hardly any secretions. In such cases, no living or dead spermatozoa could be found in the epididymal secretions and it was inferred that probably the obstruction was present in the rete testes. In the remaining eighty-six instances the obstruction was present distal to the body or the tail of the organ. The globus major in such cases was full and often the distended epididymal tubules could be seen through the tunica. No induration or nodule could either be seen or felt at the site of obstruction which was suggested clinically by sudden narrowing or collapse of the epididymis. In one instance the patient had a spermatocele attached to the head of the epididymis and the aspirated contents of the same measured $5 \mathrm{cc}$. In fifty-two cases the epididymal secretions obtained from a site proximal to the obstruction showed numerous macrophages. The characters of the macrophages and the results obtained from different staining techniques are summarized in Table 1.

The ingested spermatozoa were not necessarily dead and often the wagging movements of the tails of ingested spermatozoa could be observed. Similarly there was no evidence that only the morphologically abnormal forms were phagocytosed by the macrophages. The aspirated contents of the spermatocele also showed numerous macrophages.

In one instance the epididymal secretions contained only sperm heads. Under the light microscope they were mistaken for bacteria with bizarre movements. Their true nature was only revealed under the phase-contrast microscope and after staining with methyl green and pyronin.

Staining with scarlet red technique (Pl. 1, Fig. 1) demonstrated pigment granules which were lipoidal in nature. It served to distinguish the macrophage cells which showed no evidence of ingested spermatozoa from the precursors of spermatozoa and the epithelial cells (PI. 1, Fig. 2). Staining with Nile blue showed that the pigment concerned was lipofuscin. Davenport (1960) mentions that Nile blue is a controversial stain. However, Lillie (1954) reported that $0.1 \%$ solution of Nile blue in $1 \%$ acetic acid stains lipofuscin selectively. 
He also reported (1956) that 0.05 to $0.1 \%$ solution of Nile blue in $1 \%$ sulphuric acid stains lipofuscin and melanin dark blue or bluish green. Subsequent extraction with acetone dissolves out the stain in the case of melanin but the lipofuscin remains unaffected.

TABLE 1

CHARACTERISTICS OF SPERMIOPHAGE GELLS IN EPIDIDYMAL SECRETIONS

\begin{tabular}{|c|c|c|}
\hline Method used & $\begin{array}{l}\text { No. } \\
\text { cases }\end{array}$ & Description \\
\hline $\begin{array}{l}\text { Light microscope } \\
\text { (living condition) }\end{array}$ & 52 & $\begin{array}{l}\text { Spherical or ovoid masses of varying sizes loaded with yellow, golden } \\
\text { yellow, brown or black pigment granules which were refractile. Tails of } \\
\text { spermatozoa seen emerging from such masses. Often the pigment was con- } \\
\text { centrated at the centre to form heavily stained brown core with a } \\
\text { peripheral rim of clear cytoplasm which showed amoeboid movements. } \\
\text { Ingested spermatozoa were not necessarily dead and the wagging move- } \\
\text { ments of the tails could be noticed. }\end{array}$ \\
\hline $\begin{array}{l}\text { Under phase- } \\
\text { contrast microscope }\end{array}$ & 52 & $\begin{array}{l}\text { Ingested sperm heads were in the same focal plane as that of the nuclei of } \\
\text { the macrophages indicating that the spermatozoa were intracellular. } \\
\text { Highly refractile lipid granules noticed. During the amoeboid movements } \\
\text { there was petal-like projection of ectoplasm which was followed by a } \\
\text { flow of granuloplasm. Occasionally ingested red blood cells were noted in } \\
\text { the cytoplasm of the spermiophage cell. }\end{array}$ \\
\hline $\begin{array}{l}\text { Haematoxylin and } \\
\text { eosin stained } \\
\text { preparations }\end{array}$ & 52 & $\begin{array}{l}\text { In fixed preparations the macrophages appeared oval or circular. The } \\
\text { cell diameter ranged from } 15 \text { to } 100 \mu \text {. Cytoplasm was foamy and } \\
\text { vacuolated. Nucleus was sponge-like and was usually eccentric. Nuclear } \\
\text { shape was either circular, oval or indented. Nuclei in the multi- } \\
\text { nucleated cells were arranged in clusters like the nuclei of foreign body } \\
\text { giant cells either at the centre or at one end or were scattered irregularly } \\
\text { in the cytoplasm. Number of nuclei ranged from two to eleven. }\end{array}$ \\
\hline $\begin{array}{l}\text { Scarlet red and } \\
\text { haematoxylin }\end{array}$ & 40 & $\begin{array}{l}\text { Macrophages showed numerous lipoid granules which were stained red. } \\
\text { The cytoplasm was stained pale blue or sometimes remained unstained. } \\
\text { The nuclei of the spermiophage cells and the ingested spermatozoa were } \\
\text { stained deep blue. The size of the lipoid granules not only varied from } \\
\text { cell to cell but also varied in the different parts of the same cell. The } \\
\text { presence of lipoid granules was independent of the existence of ingested } \\
\text { spermatozoa. The pseudopodia also showed the lipoid granules. Few } \\
\text { spermiophage cells were devoid of these granules. Precursors and the } \\
\text { epithelial cells did not show the presence of similar lipoid granules. }\end{array}$ \\
\hline $\begin{array}{l}\text { Nile blue stain } \\
\text { Lillie's method }\end{array}$ & 10 & $\begin{array}{l}\text { Spermiophage cells were stained dark blue or bluish green. The time } \\
\text { required for staining was more. Nuclear staining was not achieved. } \\
\text { Results not satisfactory. }\end{array}$ \\
\hline $\begin{array}{l}\text { Methyl green and } \\
\text { pyronin technique }\end{array}$ & 5 & $\begin{array}{l}\text { Ingested pear-shaped masses which looked like sperm heads and the } \\
\text { nuclei of the spermiophage cells were stained blue and the cytoplasm } \\
\text { was stained pale red or bright red. }\end{array}$ \\
\hline
\end{tabular}

In haematoxylin and eosin preparations the macrophages were easily recognized if ingested spermatozoa were visible in the cytoplasm. In their absence it was extremely difficult to identify the spermiophage cells, because the smaller ones could be mistaken for epithelial cells. In such cases a cell was labelled as a macrophage cell only on the basis of the past experience of the author who had observed identical cells with ingested spermatozoa.

The possibility that the spermatozoa which looked as if they were ingested by the macrophages might in reality be simply adhering to the parent cell was ruled 
out by examination under the phase-contrast microscope and by the results of scarlet red staining. By means of the latter method ingested spermatozoa were noticed in between the lipoid granules. The identity of ingested spermatozoa was confirmed in a few instances by staining with methyl green and pyronin. The ingested pear-shaped masses which looked like sperm heads were rich in DNA.

In five cases large numbers of macrophages were noted in the epididymal secretions obtained from a site proximal to the obstruction. In these cases numerous living or dead spermatozoa were also present. However, surprisingly, not a single macrophage cell showed the presence of ingested spermatozoa. It was noteworthy that the pigment material in the macrophages was scanty.

Regarding the location of the macrophages, it was found that epididymal secretions collected from a site immediately proximal to the suspected clinical obstruction showed numerous macrophages without the presence of spermatozoa, whereas those from a site higher up towards the head showed numerous spermatozoa along with the macrophages. In general the epididymal secretions obtained by aspirating the head of the epididymis seldom yielded more than a couple of drops of secretion, with occasional macrophage cells. In comparison, the incision of the epididymis yielded more fluid.

In the vasectomized individuals, secretions from the proximal end of the cut vas deferens contained few macrophages. The epididymal secretions in these cases contained large numbers of macrophages. In a few instances, the epididymal secretions collected from a site distal to the suspected obstruction showed the presence of spermiophage cells.

\section{EPIDIDYMAL BIOPSIES}

The histological findings in fourteen cases of obstructive azoospermia, where the obstruction was present in rete testes, and in five cases of severe oligozoospermia are summarized in Table 2. The findings in the remaining thirty-two cases of obstructive azoospermia are presented in Table 3.

\section{Haematoxylin and eosin preparations}

Although in the majority of instances the spermiophage cells contained lipofuscin pigment, some of them contained brown material and others were only identified by their morphological characters and by the presence of ingested spermatozoa.

In the dilated tubules the lining epithelium was cuboidal or was merely reduced to a flattened layer of basal cells. In places the epithelial cells were peculiarly pale; they were low columnar, vacuolated and had increased breadth. The cilia of the individual cells were lost. The nuclei were basal and vesicular. Often all types of epithelial cells, i.e. high columnar, low columnar, cuboidal and flattened were witnessed in the same sections.

The pigment was occasionally noticed in the high columnar cells, but commonly the low cuboidal and flattened types of cells were markedly loaded with it. In the same section some tubules were rich in the pigment material while others were devoid of it. In the cuboidal cells the pigment was concentrated in the supranuclear region towards the lumina of the tubules: The biopsy

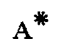


in one case showed dilated tubules which were lined by cells which were indistinguishable from the macrophage cells. These basal cells were heavily loaded with the golden yellow pigment.

When epididymal biopsies were obtained from the site of obstruction and sections were cut in the horizontal and vertical planes, dilated epididymal tubules containing masses of spermatozoa and macrophages were seen at one

TABLE 2

FINDINGS OF EPIDIDYMAL BIOPSIES IN FIVE CASES OF OLIGOZOOSPERMIA AND FOURTEEN CASES OF AZOOSPERMIA WITH OBSTRUCTION IN THE RETE TESTES

\begin{tabular}{l|l|l|l}
\hline \multicolumn{1}{c|}{ Histological findings } & $\begin{array}{c}\text { Haematoxylin } \\
\text { and eosin prepara- } \\
\text { tions }\end{array}$ & $\begin{array}{l}\text { Marshall's } \\
\text { method }\end{array}$ & $\begin{array}{l}\text { Lillie's } \\
\text { methods }\end{array}$ \\
\hline $\begin{array}{l}\text { Dilatation of the epididymal } \\
\text { tubules }\end{array}$ & Nil & Nil \\
$\begin{array}{l}\text { Lining epithelium of the epi- } \\
\text { didymal tubules }\end{array}$ & $\begin{array}{l}\text { Striated, } \\
\text { columnar with } \\
\text { sterocilia }\end{array}$ & Unstained & Unstained \\
$\begin{array}{l}\text { Pigment in the lining epithelium } \\
\text { Stray in two } \\
\text { cases }\end{array}$ & Absent & Absent \\
$\begin{array}{l}\text { Ingestion of spermatozoa by the } \\
\text { lining epithelium }\end{array}$ & Nil & Nil & Nil \\
$\begin{array}{l}\text { Breached epithelium with } \\
\text { extravasation of spermatozoa in } \\
\text { the interstitial tissues }\end{array}$ & Nil & Nil \\
$\begin{array}{l}\text { Macrophages in the lining epi- } \\
\text { thelium of tubules }\end{array}$ & Nil & Unstained & Unstained \\
$\begin{array}{l}\text { Presence of spermatozoa in the } \\
\text { lumina of the tubules }\end{array}$ & Few, in five & Unstained & Unstained \\
$\begin{array}{l}\text { Intraluminal macrophages } \\
\begin{array}{l}\text { Macrophages in the interstitial } \\
\text { tissues }\end{array}\end{array}$ & Few present \\
$\begin{array}{l}\text { Perivascular accumulation of } \\
\text { plasma cells }\end{array}$ & Absent & Few & Anstained \\
\hline
\end{tabular}

end of the section and at the other end were empty epididymal tubules lined by tall ciliated columnar epithelial cells. The latter showed few intraluminal macrophages. The interstitial tissue at the junction showed hyperplasia of macrophages and fibrosis.

\section{Results of staining with Marshall's method}

The cells of the reticulo-endothelial system were stained black. The epithelial cells remained unstained. The intraluminal, interstitial and epithelial macrophages were stained black. Nuclear staining was not achieved (Pl. 1, Fig. 3). 
Results of staining with Nile blue

The stroma, interstitial cells, epithelial cells and red blood cells were stained pale green. The intraluminal, epithelial and interstitial macrophages were stained dark blue or green. Nuclear staining was not achieved in this method and the macrophages were stained selectively. Similarly the pigment-bearing epithelial cells were also stained (Pl. 1, Fig. 4).

TABLE 3

EPIDIDYMAL BIOPSY FINDINGS IN THIRTY-TWO CASES OF OBSTRUCTIVE AZOOSPERMIA WHERE THE OBSTRUCTION WAS IN THE CAUDAL END OF EPIDIDYMIS OR VAS DEFERENS

\begin{tabular}{|c|c|c|c|}
\hline Histological findings & $\begin{array}{c}\text { Haematoxylin and eosin } \\
\text { preparations }\end{array}$ & Marshall's method & Lillie's methods \\
\hline $\begin{array}{l}\text { Dilatation of the epididymal } \\
\text { tubules }\end{array}$ & Marked in 20 cases & Marked in 20 cases & Marked in 20 cases \\
\hline $\begin{array}{l}\text { Lining epithelium of the } \\
\text { epididymal tubules }\end{array}$ & $\begin{array}{l}\text { Low columnar, in dilated } \\
\text { tubules cuboidal or } \\
\text { flattened. Cells vacuolated } \\
\text { pale stained basal nuclei }\end{array}$ & Stained in 14 cases & Stained in 20 cases \\
\hline $\begin{array}{l}\text { Pigment in the lining epi- } \\
\text { thelial cells }\end{array}$ & Present in 18 cases & $\begin{array}{l}\text { Stained in } 14 \text { cases } \\
++\end{array}$ & $\begin{array}{l}\text { Stained in } 20 \text { cases } \\
+++\end{array}$ \\
\hline $\begin{array}{l}\text { Ingestion of spermatozoa by } \\
\text { the lining epithelial cells }\end{array}$ & 2 cases & - & - \\
\hline $\begin{array}{l}\text { Breached epithelium with } \\
\text { extravasation of spermatozoa } \\
\text { in the interstitial tissues }\end{array}$ & 3 cases & - & - \\
\hline $\begin{array}{l}\text { Macrophages in the lining } \\
\text { epithelium of the tubules }\end{array}$ & 7 cases & 2 cases $t+$ & 4 cases $t+t$ \\
\hline Intraluminal macrophages & 18 cases & $\begin{array}{l}\text { Stained } \\
14 \text { cases }\end{array}$ & $\begin{array}{l}\text { Stained } \\
18 \text { cases }\end{array}$ \\
\hline $\begin{array}{l}\text { Hyperplasia of macrophages } \\
\text { in the interstitial tissues }\end{array}$ & $\begin{array}{l}\text { Loaded with pigment in } \\
8 \text { cases }\end{array}$ & $\begin{array}{l}\text { Stained } \\
\text { cases }\end{array}$ & $\begin{array}{l}\text { Stained } \\
\text { cases }\end{array}+++8$ \\
\hline $\begin{array}{l}\text { Presence of spermatozoa in } \\
\text { the lumina of the tubules }\end{array}$ & 32 cases & - & - \\
\hline $\begin{array}{l}\text { Perivascular accumulation of } \\
\text { plasma cells in the interstitial } \\
\text { tissues }\end{array}$ & 2 cases & Stained +2 cases & Stained +2 cases \\
\hline
\end{tabular}

In ten instances the paraffin sections were stained with scarlet red-haematoxylin staining technique. The intraluminal, epithelial and interstitial macrophages were stained. But the nature of the lipoid material was not specifically identified by this method. Hence for routine work the Nile blue staining method was used which is supposed to stain the lipofuscin pigment selectively.

To summarize, the study of the epididymal biopsies showed that the phagocytosis of spermatozoa in cases of obstructive azoospermia was chiefly intraluminal (Pl. 1, Fig. 5). Interspersed among the basal cells lining the epididymal tubules were macrophages which might possibly be migrating to the lumina (Pl. 1, Figs. 3 and 4). The lining epithelium of the epididymal tubules contained 
variable amounts of pigment which was golden yellow or brown. Identical pigment material was noted in the intraluminal and interstitial macrophages. Comparison of the sections stained by haematoxylin and eosin with those stained by Nile blue revealed that it was not always possible to predict, from haematoxylin and eosin preparations, which cells would pick up Nile blue stain. As a rough guide, it was assumed that the cells loaded with golden yellow pigment would do so. However, in many instances the macrophages, which were stained later on by Nile blue, contained brownish material and could not be distinguished from other eosin-stained cells.

Comparison of sections stained by these three different methods showed that the low cuboidal or flattened cells which lined the epididymal tubules and contained golden yellow pigment were stained with Nile blue and by Marshall's method. In addition the lining epithelial cells which contained no pigment and which exhibited no distinctive features were also stained. One can reasonably infer that in some cases of obstructive azoospermia, the epithelial cells lining the epididymal tubules exhibited phagocytic properties. Confirmatory evidence for this contention was obtained by the finding of ingested spermatozoa in the epithelial cells lining the epididymal tubules in two instances (Pl. 1, Fig. 6). Phagocytosis was always intraluminal. Extravasation of spermatozoa into the interstitial tissues of the epididymis was a rare phenomenon. Interstitial macrophages with ingested spermatozoa were only noticed in two instances. The intraluminal macrophages were derived from the basal layer of cells lining the epididymal tubules and not from the interstitial macrophages.

\section{DISCUSSION}

In the laboratory animals it has been shown that the lining epithelium of the epididymal tubules has phagocytic properties. Thus Mollendorf (quoted by Mason \& Shaver, 1952) showed that the epithelial cells lining the duct have capacity to absorb vital dyes like trypan blue across the blood stream.

Mason \& Shaver (1952) demonstrated that trypan blue, when injected subcutaneously in rats, is concentrated in the lining epithelium of the ductus efferens and the proximal part of the caput epididymidis. It is also taken up by the macrophages in the interstitial tissues. They showed that the dye accumulating in the intertubular connective tissue does not contribute to the intraepithelial accumulation of the dye.

Shaver (1954) demonstrated that when India ink was injected in the rete testes of rats, the ink particles were removed from the caudally directed spermatozoa by the sterocilia from which they were transferred into the columnar epithelial cells lining the epididymal tubules. He concluded that these cells have a dual polarity and are capable of absorbing highly nutritive substances carried into the epididymis. Grant (1958), using a retrograde technique of injection of trypan blue in albino rats, concluded that the cells lining the distal part of the ductus epididymis readily take up the dye, and the rarity of intracellular inclusion of the dye in this part of the duct system, reported by Mason \& Shaver (1952), is to be ascribed to the lack of opportunity rather than to an inability of these cells to ultraphagocytose the substance. 
In man, the phagocytic activity of the epididymis has not been proved in cases of obstructive azoospermia. Nelson (1952) remarked that in such cases presumably the spermatozoa were fragmented and later underwent phagocytosis. However, no decisive evidence was presented by him. The study of the epididymal secretions in cases of obstructive azoospermia proved beyond doubt the mechanism of phagocytosis which was witnessed in the majority of cases. The characters and appearance of the spermiophage cells have already been described (Table 1).

To trace the origin of the spermiophage cells two techniques have been used. The one was based on the observation that the spermiophage cells were rich in pigment lipofuscin. The demonstration of cells loaded with lipofuscin pigment in the lining epithelium of the tubules was considered to be indicative of the phagocytic nature of the cells. Confirmatory evidence for this conjecture was obtained by examination of the slide where the intraluminal and the interstitial macrophages which were distinguished easily were also stained by Nile blue. The interstitial cells, interstitial tissue and other epithelial cells remain unstained by Nile blue. In this study paraffin sections were used for the demonstration of the lipofuscin pigment and some of the pigment material might have been lost in the process of paraffin embedding and subsequent clearing with alcohol and xylol. Indeed in five instances when frozen sections were stained with Nile blue and compared with the paraffin sections similarly stained, the loss of pigment material was obvious. Statistical and quantitative deductions are therefore not permissible on the basis of the work presented here.

Montagna (1952b) reported that "the epithelial cells of the ductus efferens contain abundant sudanophilic granules. The lipids are anisotropic and reactive to the Schultz test and must be considered as unsaturated steroids". The sudanophilic material which Montagna mentions may be the pigment lipofuscin. Another observation of his reasonably supports the identity (1952b). He says "Such similar lipids are often present in the macrophages free in the lumen. As the efferent ductules blend in the ductus epididymis the lipids are lost".

Glassy \& Mostif (1956) have noted that in cases of sperm granulomas the macrophages in the interstitial tissue were loaded with golden yellow pigment, probably lipochrome. The same finding has been confirmed by Sundarasivarao (1955) who observed that the Prussian blue method showed very few phagocytes containing iron reacting pigment and most of the brown pigment was not haemosiderin. The author has also noted macrophages in the epididymal secretions which were loaded with black pigment and which failed to take up the scarlet red stain. Whether the pigment concerned was haemosiderin or not cannot be said with certainty.

According to Anderson (1957), the macrophages occurring at other sites of the body, e.g. in the lungs, spleen, liver and kidney, sometimes contain the pigment haemosiderin. Wright (1953) mentioned that in the nervous system the microglial cells are derived from reticulo-endothelial cells and are called "compound granular corpuscles" or "Gitter-Zellen". Florey (1958) has mentioned that these cells are rich in lipoid granules. Whitby \& Britton (1953) have mentioned that the monocytes are rich in lipoid granules but the nature of the lipoid material has not been explained by them. According to Boyd (1961), the 
lipochrome pigment is normally seen in the nerve cells, seminal vesicles, adrenal cortex, corpus luteum, and interstitial cells. It is produced from the cytoplasm in the process of wasting old age and cachexia.

From the above facts, it is clear that cells containing lipochrome pigment are not necessarily phagocytic in nature. Similarly, the macrophages occurring at other sites in the body are not necessarily loaded with this pigment. Nevertheless the spermiophage cells are loaded with this pigment. A possible explanation may be as follows. Berg $(1953,1954)$ has demonstrated that the sperm heads are rich in acid fast lipids. Mann (1954) has shown that the high lipid content of spermatozoa is due largely to the 'lipid sheath' or 'lipoid capsule' which encloses the sperm cells. It appears largely to consist of a lipoprotein complex. According to Pearse (1954), pigments of the lipofuscin group comprise a series of progressively oxidized compounds ranging from the unoxidized lipids to the most oxidized of lipofuscin. Gomori (1958) states that pigments of the lipoprotein group are derived from the oxidation and polymerization of unsaturated fatty acids and represent various stages in the same process. Lastly, Wintrobe (1952) has mentioned that the macrophages contain nucleases, proteinases, and carbohydrases, like microphages, but in addition are rich in lipase. Thus it is not illogical to assume that the lipofuscin pigment in macrophages in cases of obstructive azoospermia is derived from the digestion of the ingested spermatozoa.

From the data presented above it is clear that many observers have suspected that the pigment granules observed in the epithelial cells lining the epididymal tubules were related in some way to the products of sperm disintegration, but the phagocytic activity of the tubular epithelium had never been proved unequivocally in man. In the preceding paragraphs an attempt has been made to formulate a hypothesis on the basis of previously known facts and the observations reported here. Marshall's staining technique afforded confirmatory evidence. In some cases the lining epithelium of the epididymal tubules was stained along with the macrophages. Further evidence of the phagocytic activity of the tubular epithelium is afforded by the observation of sperm heads having been ingested by the epithelium of the tubule in two instances. Such an event is very rare and the author considers himself lucky to have recorded it.

A question may be asked whether the normal epithelium of the epididymal tubules in man exhibits phagocytic properties, or whether they are initiated as a result of obstruction? It may be recalled that in fourteen cases where the site of obstruction was in the rete testes, and in five cases of oligozoospermia, the epididymal biopsies when stained by Marshall's method remained unstained. It was taken to indicate that the lining epithelium exhibited no phagocytic activity. This evidence is inadequate in itself but it favours the speculation that the products of sperm disintegration stimulate the potential phagocytic properties of the epithelium of the tubule. Anderson (1957) has raised the question as to which cells can become phagocytic and suggested that though the cells of the reticulo-endothelial system are the most important phagocytic cells, all kinds of cells are probably capable of phagocytic activity under certain conditions.

In view of the work in laboratory animals quoted earlier, it may be asked whether the proximal part of the epididymis has more phagocytic activity than 
the distal part? Usually the epididymal secretions and biopsies were obtained from the site of vaso-epididymal anastomosis which was as distal as possible to minimize trauma. However, in some cases where the vasa were blocked on both sides along their entire length, samples of the epididymal secretions and biopsies were collected from the head, body and tail of the organ. The results indicate that macrophages were present in large numbers at all three sites and there was no evidence that the proximal part of the epididymis had greater phagocytic properties.

In an earlier paper (Phadke, 1963), the presence of macrophages in semen in cases of obstructive azoospermia was described. This is not a common phenomenon. The observations reported here offer a possible explanation. When the epididymal secretions were obtained from a site distal to the obstruction, in some cases intraluminal macrophages were detected. Probably they appear in the semen along with the secretions of the vas deferens if the latter is patent.

Similarly, Phadke \& Phadke (1961) reported that when obstructive azoospermia was corrected by vaso-epididymal anastomosis the initial semen samples showed large numbers of macrophages whose number eventually declined. This is to be expected, as the free intraluminal macrophages in the epididymal tubules are washed away in the initial semen samples.

The occurrence of spermiophage cells in semen in appreciable numbers in cases of severe oligozoospermia is difficult to explain unless one assumes pathological over-activity of the epididymis in the absence of obstruction.

In cases of obstructive azoospermia, and in cases where vasoligation is carried out, the products of sperm disintegration, according to the evidence presented here, are absorbed through the intact epithelial lining of the epididymal tubules at least in some cases. It is likely that during this process some antigenic components of spermatozoa are also absorbed and transferred to the basal capillaries. This mechanism may be responsible for the development of autoantibodies against spermatozoa in the blood sera of such individuals. Further work is being carried out with this in mind, and will be reported at a later date.

\section{ACKNOWLEDGMENTS}

The author is grateful to Dr G. M. Phadke, F.R.C.s., Director, Family Welfare Bureau, Bombay, for his constructive criticism and guidance in carrying out the present study, and to Mr Balkrishna Kolha for his technical assistance.

\section{REFERENCES}

Anderson, W. A. D. (1957) Pathology, pp. 23 and 81. Mosby, St. Louis.

Berg, I. W. (1953) Differential staining of spermatozoa in sections of testes. Amer. F. clin. Path. 23, 513.

Berg, I. W. (1954) An acid fast lipid from spermatozoa. A.M.A. Arch. Path. 57, 115.

Boyd, W. (1961) Textbook of pathology, p. 405. Lea \& Febiger, Philadelphia.

Davenport, H. A. (1960) Histological and histochemical techniques, p. 339. Saunders, London.

Florey, H. (1958) General pathology, p. 102. Lloyd-Luke, London.

Glassy, F. I. \& Mostofi, F. V. (1956) Spermatic granulomas of epididymis. Amer. 7. clin. Path. 26, 1303.

GomorI, G. (1958) Microscopic histochemistry, p. 135. University of Chicago Press.

GRANT, I. H. (1958) The passage of Trypan blue through the epididymis and its uptake by this organ. Stud. Fertil. 10, 95. 
LiLlie, R. D. (1954) Histopathological technique and practical histochemistry. Blakiston, New York.

Lillie, R. D. (1956) A Nile blue staining technique for the differentiation of melanin and lipofuscin. Stain Techn. 31, 151.

Mann, T. (1954) The Biochemistry of semen, p. 126. Methuen, London.

Marshall, A. H. E. (1948) A method for the demonstration of reticulo-endothelial cells in paraffin sections. 7. Path. Bact. 60, 515.

Mason, K. E. \& Shaver, S. L. (1952) Some functions of caput epididymis. Ann. N.Y. Acad. Sci. 55, 585.

Montagna, W. (1952a) The distribution of lipids, glycogen and phosphatases in the human testis. Fertil. Steril. 3, 27.

Montagna, W. (1952b) Some cytochemical observations of human testis and epididymis. Ann. $\mathcal{N} . r$. Acad. Sci. 55, 629.

NeLson, W. O. (1952) Spermatogenesis in testes of men with blocked or absent efferent ducts. Studies on Testis and Ovary Egg and Sperm. Ed. E. T. Engle. Thomas, Springfield.

Pearse, A. G. E. (1954) Histochemistry theoretical and applied, p. 427. Churchill, London.

Phadke, A. M. (1963) A new staining technique for identification and studying the macrophage cells in semen. Fertil. Steril. 14, 468.

Phadke, A. M. \& Phadke, G. M. (1961) Occurrence of macrophage cells in the semen and in the epididymis in cases of male infertility. 7 . Reprod. Fertil. 2, 400.

Shaver, S. L. (1954) The role of sterocilia in removing India ink particles from the lumen of the rat epididymis. Anat. Rec. 119, 177.

Sundarasivarao, D. (1955) Spermatozoa granuloma of the epididymis. 7. Path. Bact. $69,324$.

Whitby, L. E. H. \& Britron, C. I. C. (1953) Disorders of blood, p. 714. Churchill, London.

Wintrobe, M. M. (1952) Clinical haematology, pp. 36 and 199. Lea \& Febiger, Philadelphia.

Wright, G. P. (1953) Reticulo-endothelial system. Recent Advances in Pathology, p. 65. Ed. G. Hadfield. Churchill, London. 